\title{
The status of and future research into Myalgic Encephalomyelitis and Chronic Fatigue Syndrome: the need of accurate diagnosis, objective assessment, and acknowledging biological and clinical subgroups
}

\author{
Frank N. M. Twisk* \\ ME-de-Patiënten Foundation, Limmen, Netherlands
}

\section{Edited by:}

Niels H. Secher, University of

Copenhagen, Denmark

Reviewed by:

Niels H. Secher, University of Copenhagen, Denmark

Niels Vidiendal Olsen,

Rigshospitalet, Denmark

*Correspondence:

Frank N. M. Twisk, ME-de-Patiënten

Foundation, Zonnedauw 15, 1906

HB Limmen, Netherlands

e-mail: frank.twisk@hetnet.nl
Although Myalgic Encephalomyelitis (ME) and Chronic Fatigue Syndrome (CFS) are used interchangeably, the diagnostic criteria define two distinct clinical entities. Cognitive impairment, (muscle) weakness, circulatory disturbances, marked variability of symptoms, and, above all, post-exertional malaise: a long-lasting increase of symptoms after a minor exertion, are distinctive symptoms of ME. This latter phenomenon separates $\mathrm{ME}$, a neuro-immune illness, from chronic fatigue (syndrome), other disorders and deconditioning. The introduction of the label, but more importantly the diagnostic criteria for CFS have generated much confusion, mostly because chronic fatigue is a subjective and ambiguous notion. CFS was redefined in 1994 into unexplained (persistent or relapsing) chronic fatigue, accompanied by at least four out of eight symptoms, e.g., headaches and unrefreshing sleep. Most of the research into ME and/or CFS in the last decades was based upon the multivalent CFS criteria, which define a heterogeneous patient group. Due to the fact that fatigue and other symptoms are non-discriminative, subjective experiences, research has been hampered. Various authors have questioned the physiological nature of the symptoms and qualified ME/CFS as somatization. However, various typical symptoms can be assessed objectively using standardized methods. Despite subjective and unclear criteria and measures, research has observed specific abnormalities in ME/CFS repetitively, e.g., immunological abnormalities, oxidative and nitrosative stress, neurological anomalies, circulatory deficits and mitochondrial dysfunction. However, to improve future research standards and patient care, it is crucial that patients with post-exertional malaise (ME) and patients without this odd phenomenon are acknowledged as separate clinical entities that the diagnosis of ME and CFS in research and clinical practice is based upon accurate criteria and an objective assessment of characteristic symptoms, as much as possible that well-defined clinical and biological subgroups of ME and CFS patients are investigated in more detail, and that patients are monitored before, during and after interventions with objective measures and biomarkers.

Keywords: Myalgic Encephalomyelitis, Chronic Fatigue Syndrome, assessment, diagnosis, immune system, post-exertional malaise, subgroups

\section{INTRODUCTION}

Myalgic Encephalomyelitis (ME) and Chronic Fatigue Syndrome (CFS) have been marred by much controversy (Holgate et al., 2011), from the authenticity of the symptoms (Chalder et al., 1996; Carruthers et al., 2011) and the existence of the ME and CFS as distinct clinical entities (Barsky and Borus, 1999; Twisk and Arnoldus, 2013) to the etiology (Huibers and Wessely, 2006; Carruthers et al., 2011), the pathophysiology (Vercoulen et al., 1994; Maes and Twisk, 2010) and presumed effective interventions, e.g., cognitive behavioral therapy (CBT) and graded exercise therapies (GET) (Knoop et al., 2007; Twisk and Arnoldus, 2012).

An important part of the controversy originates from the introduction of the label CFS, but even more from the definitional criteria of this clinical entity (Fukuda et al., 1994), which define a heterogeneous population of people of chronic fatigue (Wilson et al., 2001), and the use of self-reported subjective measures for ambiguous and insignificant symptoms like "fatigue" (Jason et al., 2009). The principle feature of CFS is (unexplained) chronic fatigue (Fukuda et al., 1994).

ME, whether defined by the original criteria (Ramsay, 1988) or the proposed new criteria (Carruthers et al., 2011), is not equivalent to CFS (Fukuda et al., 1994), let alone a severe form of incapacitating chronic fatigue (Sharpe et al., 1991; Reeves et al., 2005). Distinctive symptoms of ME are profound (muscle) weakness and cognitive deficits ("brain fog"). More importantly, ME can be distinguished from other diseases, chronic fatigue and deconditioning by post-exertional "malaise": a prolonged intensification of symptoms, e.g., "brain fog" and muscle pain after a minor exertion. This distinctive phenomenon is reflected by a 
dramatic fall in maximum oxygen uptake and oxygen uptake and workload at the aerobic threshold at a second exercise test $24 \mathrm{~h}$ after the first (Snell et al., 2013) and a long-lasting increase of muscle metabolite-detecting receptors for pain and "fatigue" after moderate exercise (White et al., 2012).

Methodological issues, e.g., symptom-based criteria, the subjectivity of the symptoms, mixing patients with post-exertional "malaise" and abnormalities (ME) and patients without this phenomenon (CFS/not $\mathrm{ME}$ ) in research and clinical practice, and assessment of the clinical status and improvement thereof in trials of proposed effective therapies using subjective measures, have yielded contradictory results and have fuelled the debate.

Despite the heterogeneity of the patient population, due to the equivocal CFS criteria, various abnormalities have been observed repetitively in the CFS patient group as a whole or in substantial subgroups of the CFS population. However, scientific progress has been slow and unnecessarily obstructed by the methodological obstacles mentioned above. In addition, due to the heterogeneity of the patients studied selected by CFS criteria, it is highly unlikely that future research will reveal one or more abnormalities that are applicable to all CFS patients.

To surmount the impasse, which has lasted for decades, it is essential to improve the standards of the research into ME/CFS, it is crucial to leave the current methods behind us and to assess symptoms objectively as much as possible, to make a clear distinction between patients with and without post-exertional abnormalities, e.g., by employing repeated cardiopulmonary exercise tests, to accurately diagnose patients using ME and CFS criteria, to define clinical and biological ME and CFS patient subgroups in research studies, and to monitor patients before, during and after trials using objective measures, however, trivial this may seem. This partly due to the fact that, in contrast with other illnesses, $\mathrm{ME}$ and CFS are not yet clearly defined by distinctive biomarkers. Without doing so, the debate around ME/CFS will persist.

This article summarizes the current status and is directed to the abnormalities established repeatedly and the potential improvement of diagnosis of and research into ME and CFS.

\section{CRITERIA \\ ME (1934)}

Outbreaks of a disease resembling "atypical poliomyelitis" (Gilliam, 1938) occurred from the 1940s through the 1980s at various places over the world (The Medical Staff of The Royal Free Hospital, 1957; 1978; Hyde et al., 1992). ME was identified as a new clinical entity in 1959 (Acheson, 1959) and has been acknowledged as a disease of the central nervous system/neurological disease by the World Health Organization since 1969 (WHO, 1967). The clinical picture was defined by Ramsay and co-workers (Ramsay, 1988; Dowsett et al., 1990; Jason et al., 2012a) in the $80 \mathrm{~s}$. Distinctive symptoms of ME (Goodwin, 1981) are: profound (muscle) weakness and tenderness, easy fatigability of the muscles, neurological abnormalities, e.g., visual problems, cognitive deficits (concentration and memory problems), circulatory disturbances, and post-exertional "malaise": a (delayed) long-lasting increase of symptoms after a minor physical and mental exertion.

\section{CFS (1994)}

The diagnostic entity CFS was introduced in 1988 (Holmes et al., 1988) after an outbreak in Nevada at Lake Tahoe in the mideighties. CFS was redefined in 1994 (Fukuda et al., 1994) into clinically evaluated, unexplained (persistent or relapsing) chronic fatigue, accompanied by at least four out of a list of eight symptoms, e.g., sore throat, unrefreshing sleep, and headaches. The majority of research into ME/CFS ${ }^{1}$ in the last two decades is based upon these case criteria. Since "fatigue" and other symptoms, e.g., unrefreshing sleep, are subjective, non-specific and ambiguous, the CFS criteria select a varied population of people with chronic fatigue (Wilson et al., 2001).

\section{ME (2011)}

The heterogeneity of the CFS (Fukuda et al., 1994) patient population has impeded effective research and accurate diagnosis of patients. For that reason a group of researchers have proposed criteria (Carruthers et al., 2011) in order to distinguish ME from CFS (Fukuda et al., 1994) and chronic fatigue (Sharpe et al., 1991). According to this new criteria post-exertional "malaise" or "neuro-immune exhaustion" ("a pathological inability to produce sufficient energy on demand" resulting into symptom exacerbation, e.g., flu-like symptoms and pain, after minor exertion) is obligatory for the diagnosis ME. Post-exertional "malaise" should be accompanied by specific neurological symptoms, impaired cellular energy metabolism and/or transportation, and immune, gastro-intestinal or genitourinary symptoms.

\section{ME vs. CFS}

Although ME and CFS are considered to be interchangeable labels (WHO, 1992), criteria for ME (Carruthers et al., 2011) and CFS (Fukuda et al., 1994) define distinct, partially overlapping clinical entities (Twisk and Arnoldus, 2013). Post-exertional malaise and cognitive deficits e.g., are not mandatory for the diagnosis CFS, while these symptoms are obligatory for the diagnosis ME. "Fatigue" is not obligatory to meet the diagnosis ME. The distinction between patients with ME/CFS with post-exertional malaise and patients without post-exertional malaise is reflected by particular clinical and immunological differences (Maes et al., 2012a; Brenu et al., 2013).

\section{PREVALENCE AND IMPACT}

Nacul et al. (2011) found that $0.19 \%$ of 143,000 individuals (18-64 years) met the commonly used Fukuda criteria for CFS (Fukuda et al., 1994), while $0.11 \%$ met the more strict criteria for ME/CFS (Carruthers et al., 2003), including post-exertional malaise. Prevalence rates of ME (Carruthers et al., 2011) remain to be investigated, but based upon (Nacul et al., 2011; Jason et al., 2012b; Maes et al., 2012a; Brenu et al., 2013) it is estimated that $30-50 \%$ of the subjects meeting the CFS (Fukuda et al., 1994) criteria fulfill the more stringent criteria for ME (Carruthers et al., 2011). Patients experience significantly more impairment than patients with hypertension, congestive heart failure, type II diabetes mellitus, acute myocardial infarction, multiple sclerosis and depression (Komaroff et al., 1996). The ME/CFS criteria

\footnotetext{
${ }^{1} \mathrm{ME} / \mathrm{CFS}$ refers to ME and/or CFS.
} 
(Carruthers et al., 2003) select patients with more disability and more physical, mental and cognitive symptoms than patients with the diagnosis CFS (Fukuda et al., 1994) not meeting these criteria (Jason et al., 2012b).

\section{DIAGNOSIS}

Nowadays, the diagnoses ME and CFS are often based upon subjective measures reported by patients, e.g., fatigue (Chalder et al., 1993; Vercoulen et al., 1994) and physical functioning (Ware and Sherbourne, 1992; McHorney et al., 1993). However, to bypass problems created by ambiguous symptom-based criteria, e.g., heterogeneity of the patient population, a clinical assessment ME of CFS and its severity should be based upon objective measures as much as possible. Several distinctive symptoms can be assessed objectively (see Table 1).

Symptoms that cannot be assessed objectively easily due to their nature, are: "fatigue", widespread muscle and/or joint pain, often amplified after a (minor) exertion, hypersensitivity to light, sound, odor and chemicals, e.g., anaesthetics (likely due to "central sensitization"), thermoregulation problems and "sickness behavior." Research (Jason et al., 2014) has shown that minimum frequency and severity thresholds should be used for self-reported symptoms to reduce the likelihood of misclassification.

\section{ABNORMALITIES}

The heterogeneity of the patient population (Whistler et al., 2003) and the use of various methods and samples have contributed to conflicting results. Despite this various specific abnormalities have been observed repetitively in the ME/CFS patient population or substantial subgroup thereof (Table 2).

Various of the abnormalities mentioned in Table 2 are reflected by deviant gene expression (Kaushik et al., 2005; Whistler et al., 2005; Fuite et al., 2008; Gow et al., 2009). Aberrations at the cellular level include mitochondrial dysfunction (Booth et al., 2012), inflammation, immunosuppression, e.g., reduced Natural Killer cell lytic activity (Hardcastle et al., 2014), immune dysfunction, e.g., increased synthesis of (Th2-associated) cytokines (Fletcher et al., 2009), increased production of inducible nitric oxide (NO) synthase by peripheral lymphocytes (Maes et al., 2007b). Tissue anomalies encompass significantly low oxygen uptake by muscle cells (Vermeulen and Vermeulen van Eck, 2014), increased intramuscular acidosis after maximal voluntary contraction with significantly prolonged $\mathrm{pH}$ recovery times (Jones et al., 2012), an inverse correlation between increased skeletal muscle $\mathrm{pH}$ and reduced cerebral blood flow at rest and during dynamic stimulation (He et al., 2013), and differential expression of genes with key roles in mitochondrial function and oxidative balance in the vastus lateralis muscle (Pietrangelo et al., 2009). Neurological abnormalities in ME/CFS patients or subgroups thereof include reduced gray and white brain matter (Puri et al., 2012), increased magnetic resonance imaging (MRI) abnormalities, mainly T2 signal hyperintensities in the frontal lobes (Lange et al., 1999), significant reductions in cerebral blood flow across various brain regions (Yoshiuchi et al., 2006), spinal fluid abnormalities (Natelson et al., 2005) and increased ventricular lactate (Shungu et al., 2012).

Since many of the research studies which observed aberrations in ME/CFS compared patients with sedentary controls, the abnormalities cannot be attributed to deconditioning. Whether the name ME is appropriate or not remains subject of debate (Van der Meer and Lloyd, 2012), but various findings in ME/CFS actually indicate muscular and neurological abnormalities. However, immunological abnormalities, antigens, increased oxidative and nitrosative stress, and gastro-intestinal dysfunction seem to be at the core of the etiology of ME/CFS (Maes and Twisk, 2010). The distinction between patients meeting the proposed criteria for ME (Carruthers et al., 2011) and patients with CFS (Fukuda et al., 1994) not fulfilling these criteria is reflected by specific immunological abnormalities (Brenu et al., 2013).

Exercise and orthostatic stress seems to induce or intensify (long lasting) abnormalities in patient subgroups, e.g., a significant decrease of the oxygen consumption and workload at exhaustion and at the ventilatory (anaerobic) threshold at a second exercise test $24 \mathrm{~h}$ later (Snell et al., 2013); a long-term increase of messenger RNA (mRNA) of metabolite-detecting receptors after sustained moderate exercise (White et al., 2012); a significant prolongation of the time taken for $\mathrm{pH}$ to recover to baseline after exercise (Jones et al., 2012); reduced prefrontal oxygenation during exercise and recovery when compared to healthy controls similar in physical activity levels (Patrick Neary et al., 2008); impaired cognitive functioning $24 \mathrm{~h}$ after physically demanding exercise compared with sedentary healthy individuals (LaManca et al., 1998); and an substantially higher increase in NO metabolites in relation to workload during exercise (Suárez et al., 2010).

Although the exact etiological mechanisms remains to be elucidated, the post-exertional malaise phenomenon could arguably be explained by the observation that physical stress, particularly anaerobic exercise, can intensify pre-existing abnormalities: inflammation (Fisher-Wellman and Bloomer, 2009; Mogharnas et al., 2011; Sakharov et al., 2012), immunosuppression (Millard et al., 2013), immune dysfunction (Steensberg et al., 2001), oxidative and nitrosative stress (Bloomer et al., 2005; Fisher-Wellman and Bloomer, 2009; Sakharov et al., 2012) and hyperpermeability of the intestines (Lambert, 2009; Lamprecht and Frauwallner, 2012). Since the anaerobic threshold is already low in ME/CFS patients or subgroups (De Becker et al., 2000; Vermeulen et al., 2010), the effects of exercise programmes should be monitored objectively and continuously, e.g., by using CPET.

\section{SUBGROUPS}

\section{CLINICAL SUBGROUPS}

In addition to a breakdown into patients with post-exertional malaise (ME) and without this hallmark feature (CFS/not ME), a subdivision into subgroups based upon onset (sudden/viral? or gradual), type and severity of symptoms, gender, age, duration and/or comorbidities seems inevitable to unravel common and distinct deviant biological pathways in more detail. Potentially relevant clinical subdivisions are summarized in Table S1 (see Supplementary Material).

\section{BIOLOGICAL SUBGROUPS}

Several studies have revealed distinct biological ME/CFS patient subgroups, often associated with distinct differences in the clinical picture as illustrated in Table S2 (Supplementary Material). The most relevant subdivisions are based upon (exercise-induced) 
Table 1 | Symptoms and tests.

\begin{tabular}{|c|c|c|}
\hline Symptom & Test & References \\
\hline Loss of energy/weakness & $\begin{array}{l}\text { Cardiopulmonary exercise test (CPET) (American } \\
\text { College of Sports Medicine, 2009; Balady et al., } \\
\text { 2010) }\end{array}$ & $\begin{array}{l}\text { De Becker et al., 2000; Farquhar et al., 2002; Jones } \\
\text { et al., } 2012\end{array}$ \\
\hline Cognitive deficits & $\begin{array}{l}\text { Specific neurocognitive tests* (Wechsler, 1981; } \\
\text { Cambridge Cognition, 1999; Lezak et al., 2004; } \\
\text { Strauss et al., 2006) }\end{array}$ & $\begin{array}{l}\text { DeLuca et al., 1993, 2004; Tiersky et al., 1997; } \\
\text { Dickson et al., 2009; Thomas and Smith, 2009; } \\
\text { Cockshell and Mathias, 2010; Constant et al., } 2011\end{array}$ \\
\hline Muscle weakness & $\begin{array}{l}\text { Muscle (power and endurance) tests (Van der } \\
\text { Ploeg, 1991; Andrews et al., 1996; Wang et al., } \\
\text { 2002; Stark et al., 2011) }\end{array}$ & $\begin{array}{l}\text { Paul et al., 1999; Fulcher and White, 2000; Lawrie } \\
\text { et al., 2000; Siemionow et al., } 2004\end{array}$ \\
\hline Orthostatic intolerance & $\begin{array}{l}\text { Tilt table test (Streeten, 1987; American College of } \\
\text { Cardiology et al., 1996; Task Force for the } \\
\text { Diagnosis and Management of Syncope, 2009) }\end{array}$ & $\begin{array}{l}\text { Rowe et al., 1995; De Lorenzo et al., 1997; } \\
\text { Streeten and Anderson, 1998; Stewart et al., 1999; } \\
\text { Newton et al., 2007; Galland et al., 2008; Hoad } \\
\text { et al., 2008; Katz et al., } 2011\end{array}$ \\
\hline
\end{tabular}

Post-exertional malaise Physical

Cognitive

Visual symptoms

Sleep disturbances

Defective stress response
Repeated cardiopulmonary exercise tests, $24 \mathrm{~h}$ apart (Katch et al., 1982; Amann et al., 2004; Bensimhon et al., 2008; Balady et al., 2010)

Specific neurocognitive tests* (Wechsler, 1981; Cambridge Cognition, 1999; Lezak et al., 2004; Strauss et al., 2006), before and after a CPET or orthostatic stress

Useful field of view tests (Ball et al., 1993; Ball and Owsley, 1993) and eye movement tests (Rommelse et al., 2008)

Polysomnografic investigation (Rechtschaffen and Kales, 1968; Dumermuth et al., 1983; Lo et al., 2002; Iber et al., 2007)

Hormonal investigation (Kirschbaum et al., 1993; Holtorf, 2008; Kovacs and Ojeda, 2011; Melmed et al., 2011)
VanNess et al., 2006; Patrick Neary et al., 2008; Vermeulen et al., 2010; Snell et al., 2013

VanNess et al., 2007; Ocon et al., 2012

Leslie, 1997; Vedelago, 1997; Badham and Hutchinson, 2013; Hutchinson and Badham, 2013

Kishi et al., 2008, 2011; Decker et al., 2009

MacHale et al., 1998; Gaab et al., 2002; Cleare, 2004; Jerjes et al., 2005; Holtorf, 2008;

Torres-Harding et al., 2008; Jammes et al., 2009; Papadopoulos and Cleare, 2011; Tak et al., 2011

${ }^{*}$ Cognitive impairments can be identified if appropriate measures/tests are used (Thomas and Smith, 2009; Cockshell and Mathias, 2010).

immunological abnormalities. Acknowledging immunological, infectious and endocrine subdivisions seem to be crucial to establish the efficacy and safety of pharmacological and behavioral therapies. In addition to differential gene expression genes in all patients, upregulation and downregulation of specific genes are likely to reflect specific (biological and clinical) ME/CFS patient subgroups.

\section{DISCUSSION}

Although ME and CFS are considered to be equivalents (WHO, 1992), the diagnostic criteria for ME (Ramsay, 1988; Dowsett et al., 1990; Carruthers et al., 2011; Jason et al., 2012a) and CFS (Sharpe et al., 1991; Fukuda et al., 1994; Reeves et al., 2005) define distinct clinical, partly overlapping, entities. CFS criteria focus primarily on chronic fatigue, which, due to is nature, is a subjective and ambiguous criterion (Jason et al., 2010, 2011a; Davenport et al., 2011). ME is principally characterized by neurocognitive impairment, (muscle) weakness and sleep disturbances, but the distinctive feature of $\mathrm{ME}$ is post-exertional "malaise": a (long-lasting) aggravation of symptoms, e.g., pain, "brain fog" and weakness, after a minor physical or mental exertion (Carruthers et al., 2011; Maes et al., 2012a).
The question whether the label ME is appropriate (Baraniuk et al., 2005; Schutzer et al., 2011) or not remains to be established, but considering the confusion due to the introduction of chronic fatigue as the principle criterion and the use of symptom-based criteria and questionnaires in clinical practice and research, it seems crucial to assess various characteristic symptoms objectively and to make a clear distinction between patients with postexertional malaise (ME) and patients without post-exertional malaise. Objective tests, e.g., repeated exercise tests (CPETs) and tilt table testing, could be employed as a solid basis for the diagnosis, the validation, adjustment and refinement of ME (Carruthers et al., 2011) and CFS (Fukuda et al., 1994) criteria and the definition of clinical ME and CFS patients subgroups in research.

Trials into the efficacy and safety of pharmacological (Fluge etal., 2011; Watt et al., 2012) and behavioral therapies, e.g., CBT and GET (Knoop et al., 2007; Heins et al., 2010; White et al., 2011), should employ objective measures of the clinical status and improvement thereof and biomarkers to establish the effects of these therapies in specific clinical and biological subgroups (Kindlon, 2012). To unravel the enigma and to resolve the controversy, patients should be monitored before, during and after potentially effective therapies in research and clinical practice using objective measures 
Table 2 | Abnormalities in ME/CFS.

\begin{tabular}{|c|c|}
\hline Abnormality & References \\
\hline $\begin{array}{l}\text { Immunological aberrations (inflammation, immune activation, } \\
\text { immunosuppression and immune dysfunction); }\end{array}$ & $\begin{array}{l}\text { Klimas et al., 1990; Fletcher et al., 2009; Lorusso et al., 2009; } \\
\text { Meeus et al., 2009; Brenu et al., 2011; Maes et al., 2012b }\end{array}$ \\
\hline consistent with processes observed during (latent) infection; & Lloyd et al., 1993; Kerr et al., 2008a; Broderick et al., 2010 \\
\hline Intestinal dysbiosis, inflammation and hyperpermeability, & $\begin{array}{l}\text { Maes et al., 2007a; Sheedy et al., 2009; Lakhan and Kirchgessner, } \\
\text { 2010; De Meirleir et al., 2013; Frémont et al., } 2013\end{array}$ \\
\hline associated with systemic immune system abnormalities; & Maes et al., 2012c; Groeger et al., 2013 \\
\hline (reactivating and/or persistent) infections; & $\begin{array}{l}\text { Hilgers and Frank, 1996; Chia and Chia, 2003; Nicolson et al., 2003; } \\
\text { Chia et al., 2010; Chapenko et al., } 2012\end{array}$ \\
\hline Elevated oxidative and nitrosative stress; & $\begin{array}{l}\text { Zhang et al., 1995; Kennedy et al., 2010; Maes and Twisk, 2010; } \\
\text { Tomic et al., } 2012\end{array}$ \\
\hline Mitochondrial dysfunction and damage to mitochondria; & $\begin{array}{l}\text { Behan et al., 1991; Pietrangelo et al., 2009; Booth et al., 2012; } \\
\text { Meeus et al., } 2013\end{array}$ \\
\hline Hypovolemia, diminished cardiac output and & $\begin{array}{l}\text { Streeten and Bell, 1998; Hurwitz et al., 2009; Miwa and Fujita, 2009; } \\
\text { Hollingsworth et al., } 2012\end{array}$ \\
\hline blood and oxygen supply deficits to muscles and brain, & McCully and Natelson, 1999; Biswal et al., 2011; Ocon, 2013 \\
\hline especially in an upright position and during exercise; & $\begin{array}{l}\text { LaManca et al., 1999; Peckerman et al., 2003; Wyller et al., 2007; } \\
\text { Patrick Neary et al., } 2008\end{array}$ \\
\hline Reduced (maximum) oxygen uptake; & $\begin{array}{l}\text { Farquhar et al., 2002; Weinstein et al., 2009; Vermeulen et al., 2010; } \\
\text { Jones et al., } 2012\end{array}$ \\
\hline Neurological abnormalities; & $\begin{array}{l}\text { Lange et al., 2005; Chen et al., 2008; Puri et al., 2012; Natelson, } \\
2013\end{array}$ \\
\hline $\begin{array}{l}\text { Hypocortisolism/blunted hypothalamic-pituitary-adrenal (HPA) axis } \\
\text { response; }\end{array}$ & $\begin{array}{l}\text { Demitrack et al., 1991; Lorusso et al., 2009; Papadopoulos and } \\
\text { Cleare, 2011; Tak et al., } 2011\end{array}$ \\
\hline Ion channel dysfunction (channelopathy); & $\begin{array}{l}\text { Watson et al., 1997; Whistler et al., 2005; Broderick et al., 2006; } \\
\text { Cameron et al., } 2007\end{array}$ \\
\hline A deviant physiological responses to exertion & $\begin{array}{l}\text { Thambirajah et al., 2008; Jones et al., 2012; Light et al., 2012; Smylie } \\
\text { et al., 2013; Snell et al., } 2013\end{array}$ \\
\hline
\end{tabular}

(Kindlon, 2012), e.g., oxygen uptake at the anaerobic threshold and maximum oxygen uptake (VO2max), and biomarkers, e.g., (exercise-induced) cytokine levels.

\section{CONCLUSION}

Looking at the definitional criteria of ME, e.g., (muscle) weakness, cognitive impairment, but above all post-exertional "malaise," ME is not equivalent to CFS, let alone chronic fatigue. The introduction of the label CFS, but more importantly a fatigue-based case definition, have resulted into research of a heterogeneous patient population of patients with chronic fatigue. Combined with the use of subjective measures this has created confusion and controversy.

Several authors have questioned the validity and nature of symptoms reported by patients. This debate can be resolved by assessing characteristic symptoms using objective methods, if possible, e.g., repeated exercise tests, cognitive tests, orthostatic testing and visual tests.

Despite the ambiguous CFS criteria and methods applied, researchers have observed various specific abnormalities repeatedly, e.g., (reactivating or chronic) infections, immunological anomalies (inflammation, immune activation and dysfunction), and long lasting deviant effects of exercise, in the ME/CFS patient population or substantial subgroups thereof.
However, in order to advance in research and clinical practice, to unravel the enigmatic cause(s) of ME and CFS and to develop effective therapies, it seems crucial (a) that patients with postexertional "malaise" (ME) and "CFS" patients without postexertional phenomena are acknowledged as two separate clinical and research entities; (b) that typical symptoms of ME and CFS are assessed objectively as much as possible; (c) that well-defined clinical subgroups of ME and CFS, e.g., patients with orthostatic intolerance or patients with sudden-onset, are investigated in more detail; (d) that biomarkers, e.g., immunological status in rest and after exertion, are used to distinguish biological subtypes in research; and (e) that trials into the efficacy of therapies use objective measures of the clinical status and biomarkers to establish the effects of these therapies in ME or CFS patients or subgroups thereof impartially, e.g., by a (positive) change in the oxygen uptake at the anaerobic threshold and cognitive tests scores.

Considering the central role of post-exertional and cognitive impairment ("brain fog") in ME/CFS, interesting areas of research include exercise-induced abnormalities, e.g., immune responses, oxidative and nitrosative stress, oxygen uptake, mitochondrial dysfunction, and brain energetics before, during and after exercise and cognitive stimulation (Quistorff et al., 2008; Bergersen and Gjedde, 2012; Shungu et al., 2012). 


\section{SUPPLEMENTARY MATERIAL}

The Supplementary Material for this article can be found online at: http://www.frontiersin.org/journal/10.3389/fphys.2014. 00109/abstract

\section{REFERENCES}

(1978). Epidemic myalgic encephalomyelitis. Br. Med. J. 1, 1436-1437. doi: 10.1136/bmj.1.2791.1436-a

Aschbacher, K., Adam, E. K., Crofford, L. J., Kemeny, M. E., Demitrack, M. A., and Ben-Zvi, A. (2012). Linking disease symptoms and subtypes with personalized systems-based phenotypes: a proof of concept study. Brain Behav. Immun. 26, 1047-1056. doi: 10.1016/j.bbi.2012.06.002

American College of Cardiology, Benditt, D. G., Ferguson, D. W., Grubb, B. P., Kapoor, W. N., Kugler, J., et al. (1996). Tilt table testing for assessing syncope. J. Am. Coll. Cardiol. 28, 263-275. doi: 10.1016/0735-1097(96)00236-7

American College of Sports Medicine. (2009). ACSM's Guidelines for Exercise Testing and Prescription, 8th Edn. Ambler, PA: Lippincott Williams and Wilkins.

Acheson, E. D. (1959). The clinical syndrome variously called benign myalgic encephalomyelitis, Iceland disease and epidemic neuromyasthenia. Am. J. Med. 26, 569-595. doi: 10.1016/0002-9343(59)90280-3

Amann, M., Subudhi, A. W., Walker, J., Eisenman, P., Shultz, B., and Foster, C. (2004). An evaluation of the predictive validity and reliability of ventilatory threshold. Med. Sci. Sports Exerc. 36, 1716-1722. doi: 10.1249/01.MSS.0000142305.18543.34

Andrews, A. W., Thomas, M. W., and Bohannon, R. W. (1996). Normative values for isometric muscle force measurements obtained with hand-held dynamometers. Phys. Ther. 76, 248-259.

Badham, S. P., and Hutchinson, C. V. (2013). Characterising eye movement dysfunction in myalgic encephalomyelitis/chronic fatigue syndrome. Graefes Arch. Clin. Exp. Ophthalmol. 251, 2769-2776. doi: 10.1007/s00417-013-2431-3

Balady, G. J., Arena, R., Sietsema, K., Myers, J., Coke, L., Fletcher, G. F., et al. (2010). Clinician's Guide to cardiopulmonary exercise testing in adults: a scientific statement from the American Heart Association. Circulation 122, 191-225. doi: 10.1161/CIR.0b013e3181e52e69

Ball, K., and Owsley, C. (1993). The useful field of view test: a new technique for evaluating age-related declines in visual function. J. Am. Optom. Assoc. 64 71-79.

Ball, K., Owsley, C., Sloane, M. E., Roenker, D. L., and Bruni, J. R. (1993). Visual attention problems as a predictor of vehicle crashes in older drivers. Invest. Ophthalmol. Vis. Sci. 34, 3110-3123.

Baraniuk, J. N., Casado, B., Maibach, H., Clauw, D. J., Pannell, L. K., and Hess, S. S. (2005). A chronic fatigue syndrome - related proteome in human cerebrospinal fluid. BMC Neurol. 5:22. doi: 10.1186/1471-2377-5-22

Barsky, A. J., and Borus, J. F. (1999). Functional somatic syndromes. Ann. Intern. Med. 130, 910-921. doi: 10.7326/0003-4819-130-11-199906010-00016

Behan, W. M., More, I. A., and Behan, P. O. (1991). Mitochondrial abnormalities in the postviral fatigue syndrome. Acta Neuropathol. 83, 61-65. doi: 10.1007/BF00294431

Bensimhon, D. R., Leifer, E. S., Ellis, S. J., Fleg, J. L., Keteyian, S. J., Piña, I. L., et al. (2008). Reproducibility of peak oxygen uptake and other cardiopulmonary exercise testing parameters in patients with heart failure (from the Heart Failure and A Controlled Trial Investigating Outcomes of exercise traiNing). Am. J. Cardiol. 102, 712-717. doi: 10.1016/j.amjcard.2008.04.047

Bergersen, L. H., and Gjedde, A. (2012). Is lactate a volume transmitter of metabolic states of the brain? Front. Neuroenergetics 4:5. doi: 10.3389/fnene.2012.00005

Biswal, B., Kunwar, P., and Natelson, B. H. (2011). Cerebral blood flow is reduced in chronic fatigue syndrome as assessed by arterial spin labeling. J. Neurol. Sci. 301, 9-11. doi: 10.1016/j.jns.2010.11.018

Bloomer, R. J., Goldfarb, A. H., Wideman, L., McKenzie, M. J., and Consitt, L. A. (2005). Effects of acute aerobic and anaerobic exercise on blood markers of oxidative stress. J. Strength Cond. Res. 19, 276-285. doi: 10.1519/14823.1

Booth, N. E., Myhill, S., and McLaren-Howard, J. (2012). Mitochondrial dysfunction and the pathophysiology of myalgic encephalomyelitis/chronic fatigue syndrome (ME/CFS). Int. J. Clin. Exp. Med. 5, 208-220.

Brenu, E. W., Johnston, S., Hardcastle, S. L., Huth, T. K., Fuller, K., Ramos, S. B., et al. (2013). Immune abnormalities in patients meeting new diagnostic criteria for chronic fatigue syndrome/Myalgic Encephalomyelitis. J. Mol. Biomark. Diagn. 4, 152. doi: 10.4172/2155-9929.1000152
Brenu, E. W., van Driel, M. L., Staines, D. R., Ashton, K. J., Ramos, S. B., Keane, J., et al. (2011). Immunological abnormalities as potential biomarkers in chronic fatigue syndrome/myalgic encephalomyelitis. J. Transl. Med. 9, 81. doi: 10.1186/1479-5876-9-81

Broderick, G., Craddock, R. C., Whistler, T., Taylor, R., Klimas, N., and Unger, E. R. (2006). Identifying illness parameters in fatiguing syndromes using classical projection methods. Pharmacogenomics 7, 407-419. doi: 10.2217/14622416.7.3.407

Broderick, G., Fuite, J., Kreitz, A., Vernon, S. D., Klimas, N., and Fletcher, M. A. (2010). A formal analysis of cytokine networks in chronic fatigue syndrome. Brain Behav. Immun. 24, 1209-1217. doi: 10.1016/j.bbi.2010.04.012

Cameron, B., Galbraith, S., Zhang, Y., Davenport, T., Vollmer-Conna, U., Wakefield, D., et al. (2007). Gene expression correlates of postinfective fatigue syndrome after infectious mononucleosis. J. Infect. Dis. 196, 56-66. doi: $10.1086 / 518614$

Cambridge Cognition (1999). CANTAB. Cambridge Cognition, Cambridge.

Carruthers, B. M., Jain, A. K., de Meirleir, K. L., Peterson, D. L., Klimas, N. G., Lerner, A. M., et al. (2003). Myalgic encephalomyelitis/chronic fatigue syndrome - clinical working case definition, diagnostic and treatment protocols. J. Chronic Fatigue Syndr. 11, 7-115. doi: 10.1300/J092v11n01 02

Carruthers, B. M., van de Sande, M. I., de Meirleir, K. L., Klimas, N. G., Broderick, G., Mitchell, T., et al. (2011). Myalgic Encephalomyelitis: international consensus criteria. J. Intern. Med. 270, 327-338. doi: 10.1111/j.1365-2796.2011 02428.x

Chalder, T., Berelowitz, G., Pawlikowska, T., Watts, L., Wessely, S., Wright, D., et al. (1993). Development of a fatigue scale. J. Psychosom. Res. 37, 147-153. doi: 10.1016/0022-3999(93)90081-P

Chalder, T., Power, M. J., and Wessely, S. (1996). Chronic fatigue in the community: 'a question of attribution'. Psychol. Med. 26, 791-800. doi: 10.1017/S0033291700037818

Chapenko, S., Krumina, A., Logina, I., Rasa, S., Chistjakovs, M., Sultanova, A., et al. (2012). Association of active human herpesvirus-6, -7 and parvovirus B19 infection with clinical outcomes in patients with myalgic encephalomyelitis/chronic fatigue syndrome. Adv. Virol. 2012:205085. doi: 10.1155/2012/205085

Chen, R., Liang, F. X., Moriya, J., Yamakawa, J., Sumino, H., Kanda, T., et al. (2008). Chronic fatigue syndrome and the central nervous system. J. Int. Med. Res. 36, 867-874. doi: 10.1177/147323000803600501

Chia, J., Chia, A., Voeller, M., Lee, T., and Chang, R. (2010). Acute enterovirus infection followed by myalgic encephalomyelitis/chronic fatigue syndrome (ME/CFS) and viral persistence. J. Clin. Pathol. 63, 165-168. doi: 10.1136/jcp.2009.070466

Chia, J. K., and Chia, A. (2003). Diverse etiologies for chronic fatigue syndrome. Clin. Infect. Dis. 36, 671-672. doi: 10.1086/367666

Clark, M. R., Katon, W., Russo, J., Kith, P., Sintay, M., and Buchwald, D. (1995) Chronic fatigue: risk factors for symptom persistence in a $21 / 2$-year follow-up study. Am. J. Med. 98, 187-195. doi: 10.1016/S0002-9343(99)80403-3

Claypoole, K. H., Noonan, C., Mahurin, R. K., Goldberg, J., Erickson, T., and Buchwald, D. (2007). A twin study of cognitive function in chronic fatigue syndrome: the effects of sudden illness onset. Neuropsychology 21, 507-513. doi: 10.1037/0894-4105.21.4.507

Cleare, A. J. (2004). The HPA axis and the genesis of chronic fatigue syndrome Trends Endocrinol. Metab. 15, 55-59. doi: 10.1016/j.tem.2003.12.002

Cockshell, S. J., and Mathias, J. L. (2010). Cognitive functioning in chronic fatigue syndrome: a meta-analysis. Psychol. Med. 40, 1253-1267. doi: 10.1017/S0033291709992054

Constant, E. L., Adam, S., Gillain, B., Lambert, M., Masquelier, E., and Seron, X. (2011). Cognitive deficits in patients with chronic fatigue syndrome compared to those with major depressive disorder and healthy controls. Clin. Neurol. Neurosurg. 113, 295-302. doi: 10.1016/j.clineuro.2010.12.002

Cook, D. B., Lange, G., DeLuca, J., and Natelson, B. H. (2001). Relationship of brain MRI abnormalities and physical functional status in chronic fatigue syndrome. Int. J. Neurosci. 107, 1-6. doi: 10.3109/00207450109149754

Cook, D. B., Nagelkirk, P. R., Peckerman, A., Poluri, A., Mores, J., and Natelson, B. H. (2005). Exercise and cognitive performance in chronic fatigue syndrome. Med. Sci. Sports Exerc. 37, 1460-1467. doi: 10.1249/01.mss.0000179921. 48404.ef

Davenport, T. E., Stevens, S. R., Baroni, K., M, V. N., and Snell, C. R. (2011) Diagnostic accuracy of symptoms characterising chronic fatigue syndrome. Disabil. Rehabil. 33, 1768-1775. doi: 10.3109/09638288.2010.546936 
De Becker, P., McGregor, N., and de Meirleir, K. (2002). Possible triggers and mode of onset of chronic fatigue syndrome. J. Chronic Fatigue Syndr. 10, 3-18. doi: 10.1300/J092v10n02

De Becker, P., Roeykens, J., Reynders, M., McGregor, N., and de Meirleir, K. (2000). Exercise capacity in chronic fatigue syndrome. Arch. Intern. Med. 160, 3270-3277. doi: 10.1001/archinte.160.21.3270

Decker, M. J., Tabassum, H., Lin, J. M., and Reeves, W. C. (2009) Electroencephalographic correlates of chronic fatigue syndrome. Behav. Brain Funct. 5, 43. doi: 10.1186/1744-9081-5-43

De Lorenzo, F., Hargreaves, J., and Kakkar, V. V. (1997). Pathogenesis and management of delayed orthostatic hypotension in patients with chronic fatigue syndrome. Clin. Auton. Res. 7, 185-190. doi: 10.1007/BF02267980

DeLuca, J., Christodoulou, C., Diamond, B. J., Rosenstein, E. D., Kramer, N., and Natelson, B. H. (2004). Working memory deficits in chronic fatigue syndrome: differentiating between speed and accuracy of information processing. J. Int. Neuropsychol. Soc. 10, 101-109. doi: 10.1017/S1355617704101124

DeLuca, J., Johnson, S. K., Ellis, S. P., and Natelson, B. H. (1997a). Sudden vs gradual onset of chronic fatigue syndrome differentiates individuals on cognitive and psychiatric measures. J. Psychiatr. Res. 31, 83-90. doi: 10.1016/S00223956(96)00052-0

DeLuca, J., Johnson, S. K., Ellis, S. P., and Natelson, B. H. (1997b). Cognitive functioning is impaired in patients with chronic fatigue syndrome devoid of psychiatric disease. J. Neurol. Neurosurg. Psychiatr. 62, 151-155. doi: 10.1136/jnnp.62.2.151

DeLuca, J., Johnson, S. K., and Natelson, B. H. (1993). Information processing efficiency in chronic fatigue syndrome and multiple sclerosis. Arch. Neurol. 50, 301-304.

De Meirleir, K. L., Khaiboullina, S. F., Frémont, M., Hulstaert, J., Rizvanov, A. A., Palotás, A., et al. (2013). Plasmacytoid dendritic cells in the duodenum of individuals diagnosed with myalgic encephalomyelitis are uniquely immunoreactive to antibodies to human endogenous retroviral proteins. In Vivo 27, 177-187

Demitrack, M. A., Dale, J. K., Straus, S. E., Laue, L., Listwak, S. J., Kruesi, M. J., et al. (1991). Evidence for impaired activation of the hypothalamic-pituitary-adrena axis in patients with chronic fatigue syndrome. J. Clin. Endocrinol. Metab. 73, 1224-1234. doi: 10.1210/jcem-73-6-1224

Dickson, A., Toft, A., and O'Carroll, R. E. (2009). Neuropsychological functioning, illness perception, mood and quality of life in chronic fatigue syndrome, autoimmune thyroid disease and healthy participants. Psychol. Med. 39, 1567-1576. doi: 10.1017/S0033291708004960

Dowsett, E. G., Ramsay, A. M., McCartney, R. A., and Bell, E. J. (1990). Myalgic encephalomyelitis - a persistent enteroviral infection? Postgrad. Med. J. 66 526-530. doi: 10.1136/pgmj.66.777.526

Dumermuth, G., Lange, B., Lehmann, D., Meier, C. A., Dinkelmann, R., and Molinari, L. (1983). Spectral analysis of all-night sleep EEG in healthy adults. Eur. Neurol. 22, 322-339. doi: 10.1159/000115579

Farquhar, W. B., Hunt, B. E., Taylor, J. A., Darling, S. E., and Freeman, R. (2002). Blood volume and its relation to peak $\mathrm{O}(2)$ consumption and physical activity in patients with chronic fatigue. Am. J. Physiol. Heart Circ. Physiol. 282, H66-H71.

Fisher-Wellman, K., and Bloomer, R. J. (2009). Acute exercise and oxidative stress: a 30 year history. Dyn. Med. 8, 1. doi: 10.1186/1476-5918-8-1

Fletcher, M. A., Zeng, X. R., Barnes, Z., Levis, S., and Klimas, N. G. (2009). Plasma cytokines in women with chronic fatigue syndrome. J. Transl. Med. 7, 96. doi: 10.1186/1479-5876-7-96

Fluge, Ø., Bruland, O., Risa, K., Storstein, A., Kristoffersen, E. K., Sapkota, D., et al. (2011). Benefit from B-lymphocyte depletion using the anti-CD20 antibody rituximab in chronic fatigue syndrome. A double-blind and placebo-controlled study. PLoS ONE 6:e26358. doi: 10.1371/journal.pone.0026358

Frémont, M., Coomans, D., Massart, S., and de Meirleir, K. (2013). Highthroughput $16 \mathrm{~S}$ rRNA gene sequencing reveals alterations of intestinal microbiota in myalgic encephalomyelitis/chronic fatigue syndrome patients. Anaerobe 22, 50-56. doi: 10.1016/j.anaerobe.2013.06.002

Friedberg, F., Dechene, L., and McKenzie, M. J. 2nd, Fontanetta, R. (2000). Symptom patterns in long-duration chronic fatigue syndrome. J. Psychosom. Res. 48, 59-68. doi: 10.1016/S0022-3999(99)00077-X

Fuite, J., Vernon, S. D., and Broderick, G. (2008). Neuroendocrine and immune network re-modeling in chronic fatigue syndrome: an exploratory analysis. Genomics 92, 393-399. doi: 10.1016/j.ygeno.2008.08.008
Fukuda, K., Straus, S. E., Hickie, I., Sharpe, M., Dobbins, J. G., and Komaroff, A. L. (1994). The chronic fatigue syndrome: a comprehensive approach to its definition and study. Ann. Intern. Med. 121, 953-959. doi: 10.7326/0003-4819121-12-199412150-00009

Fulcher, K. Y., and White, P. D. (2000). Strength and physiological response to exercise in patients with chronic fatigue syndrome. J. Neurol. Neurosurg. Psychiatr. 69, 302-307. doi: 10.1136/jnnp.69.3.302

Gaab, J., Engert, V., Heitz, V., Schad, T., Schürmeyer, T. H., and Ehlert, U. (2004) Associations between neuroendocrine responses to the insulin tolerance test and patient characteristics in chronic fatigue syndrome. J. Psychosom. Res. 56, 419-424. doi: 10.1016/S0022-3999(03)00625-1

Gaab, J., Hüster, D., Peisen, R., Engert, V., Heitz, V., Schad, T., et al. (2002). Hypothalamic-pituitary-adrenal axis reactivity in chronic fatigue syndrome and health under psychological, physiological, and pharmacological stimulation. Psychosom. Med. 64, 951-962. doi: 10.1097/01.PSY.0000038937.67401.61

Galland, B. C., Jackson, P. M., Sayers, R. M., and Taylor, B. J. (2008). A matched case control study of orthostatic intolerance in children/adolescents with chronic fatigue syndrome. Pediatr. Res. 63, 196-202. doi: 10.1203/PDR.0b013e31815ed612

Gilliam, A. G. (1938). Epidemiological Study on an Epidemic, Diagnosed as Poliomyelitis, Occurring Among the Personnel of Los Angeles County General Hospital During the Summer of 1934. Public Health Bulletin: 240. Washington, DC: National Institutes of Health (US).

Goodwin, C. (1981). Was it benign myalgic encephalomyelitis? Lancet 1, 37-38. doi: 10.1016/S0140-6736(81)90134-3

Gow, J. W., Hagan, S., Herzyk, P., Cannon, C., Behan, P. O., and Chaudhuri, A. (2009). A gene signature for post-infectious chronic fatigue syndrome. BMC Med. Genomics 2:38. doi: 10.1186/1755-8794-2-38

Groeger, D., O’Mahony, L., Murphy, E. F., Bourke, J. F., Dinan, T. G., Kiely, B., et al (2013). Bifidobacterium infantis 35624 modulates host inflammatory processes beyond the gut. Gut Microbes 4, 325-339. doi: 10.4161/gmic.25487

Hardcastle, S. L., Brenu, E. W., Johnston, S., Nguyen, T., Huth, T., Kaur, M., et al. (2014). Analysis of the relationship between immune dysfunction and symptom severity in patients with Chronic Fatigue Syndrome/Myalgic Encephalomyelitis (CFS/ME). J. Clin. Cell. Immunol. 5, 190. doi: 10.4172/2155-9899.1000190

He, J., Hollingsworth, K. G., Newton, J. L., and Blamire, A. M. (2013). Cerebral vascular control is associated with skeletal muscle $\mathrm{pH}$ in chronic fatigue syndrome patients both at rest and during dynamic stimulation. Neuroimage Clin. 2, 168-173. doi: 10.1016/j.nicl.2012.12.006

Heins, M. J., Knoop, H., Prins, J. B., Stulemeijer, M., van der Meer, J. W. M., and Bleijenberg, G. (2010). Possible detrimental effects of cognitive behaviour therapy for chronic fatigue syndrome. Psychother. Psychosom. 79, 249-256. doi: $10.1159 / 000315130$

Hilgers, A., and Frank, J. (1996). Chronic fatigue syndrome: evaluation of a 30 criteria score and correlation with immune activation. J. Chronic Fatigue Syndr. 2, 35-47. doi: 10.1300/J092v02n04_04

Hoad, A., Spickett, G., Elliott, J., and Newton, J. (2008). Postural orthostatic tachycardia syndrome is an under-recognized condition in chronic fatigue syndrome. QJM 101, 961-965. doi: 10.1093/qjmed/hcn123

Holgate, S. T., Komaroff, A. L., Mangan, D., and Wessely, S. (2011). Chronic fatigue syndrome: understanding a complex illness. Nat. Rev. Neurosci. 12, 539-544. doi: $10.1038 / \mathrm{nrn} 3087$

Hollingsworth, K. G., Hodgson, T., Macgowan, G. A., Blamire, A. M., and Newton, J. L. (2012). Impaired cardiac function in chronic fatigue syndrome measured using magnetic resonance cardiac tagging. J. Intern. Med. 271, 264-270. doi: $10.1111 / j .1365-2796.2011 .02429 . x$

Holmes, G. P., Kaplan, J. E., Gantz, N. M., Komaroff, A. L., Schonberger, L. B., Straus, S. E., et al. (1988). Chronic fatigue syndrome: a working case definition. Ann. Intern. Med. 108, 387-389.

Holtorf, K. (2008). Diagnosis and treatment of hypothalamic-pituitaryadrenal (HPA) axis dysfunction in patients with chronic fatigue syndrome (CFS) and fibromyalgia (FM). J. Chronic Fatigue Syndr. 14, 59-88. doi: 10.1300/J092v14n03_06

Huibers, M. J., and Wessely, S. (2006). The act of diagnosis: pros and cons of labelling chronic fatigue syndrome. Psychol. Med. 36, 895-900. doi: 10.1017/S0033291705006926

Hurwitz, B. E., Coryell, V. T., Parker, M., Martin, P., Laperriere, A., Klimas, N. G., et al. (2009). Chronic fatigue syndrome: illness severity, sedentary lifestyle, 
blood volume and evidence of diminished cardiac function. Clin. Sci. 118, 125-135. doi: 10.1042/CS20090055

Hutchinson, C. V., and Badham, S. P. (2013). Patterns of abnormal visual attention in myalgic encephalomyelitis. Optom. Vis. Sci. 90, 607-614. doi: 10.1097/OPX.0b013e318294c232

Hyde, B. M., Goldstein, J., and Levine, P. (eds.). (1992). The Clinical and Scientific Basis of Myalgic Encephalomyelitis/Chronic Fatigue Syndrome. Ottawa, ON: The Nightingale Research Foundation.

Iber, C., Ancoli-Israel, S., Chesson, A., and Quan, S. F. (2007). The AASM Manual for the Scoring of Sleep and Associated Events: Rules, Terminology, and Technical Specifications. 1st Edn. Westchester, IL: American Academy of Sleep Medicine.

Jammes, Y., Steinberg, J. G., and Delliaux, S. (2012). Chronic fatigue syndrome: acute infection and history of physical activity affect resting levels and response to exercise of plasma oxidant/antioxidant status and heat shock proteins. J. Intern. Med. 272, 74-84. doi: 10.1111/j.1365-2796.2011.02488.x

Jammes, Y., Steinberg, J. G., Delliaux, S., and Brégeon, F. (2009). Chronic fatigue syndrome combines increased exercise-induced oxidative stress and reduced cytokine and Hsp responses. J. Intern. Med. 266, 196-206. doi: 10.1111/j.13652796.2009.02079.x

Jason, L. A., Brown, A., Clyne, E., Bartgis, L., Evans, M., and Brown, M. (2012b). Contrasting case definitions for chronic fatigue syndrome, myalgic encephalomyelitis/chronic fatigue syndrome and myalgic encephalomyelitis. Eval. Health Prof. 35, 280-304. doi: 10.1177/0163278711424281

Jason, L. A., Damrongvachiraphan, D., Hunnell, J., Bartgis, L., Brown, A., Evans, M., et al. (2012a). Myalgic encephalomyelitis case definitions. Automatic Control Physiol. State Funct. 1:K110601. doi: 10.4303/acpsf/K110601

Jason, L. A., Evans, M., Brown, A., Brown, M., Porter, N., Hunnell, J., et al. (2010). Sensitivity and specificity of the CDC empirical chronic fatigue syndrome case definition. Psychology 1, 9-16. doi: 10.4236/psych.2010.11002

Jason, L. A., Evans, M., Brown, M., Porter, N., Brown, A., Hunnell, J., et al. (2011a). Fatigue scales and chronic fatigue syndrome: issues of sensitivity and specificity. Disabil. Stud. Q. 31, pii: 1375.

Jason, L. A., Jessen, T., Porter, N., Boulton, A., Gloria-Njoku, M., and Friedberg, F. (2009). Examining types of fatigue among individuals with ME/CFS. Disabil. Stud. Q. 29. Available online at: http://www.dsq-sds.org/article/view/938/1113.

Jason, L. A., Sunnquist, M., Brown, A., Evans, M., Vernon, S. D., Furst, J. D., et al. (2014). Examining case definition criteria for chronic fatigue syndrome and myalgic encephalomyelitis. Fatigue. Biomed. Health Behav. 2, 40-56. doi: 10.1080/21641846.2013.862993

Jason, L. A., Porter, N., Hunnell, J., Brown, A., Rademaker, A., and Richman, J. A. (2011b). A natural history study of chronic fatigue syndrome. Rehabil. Psychol. 56, 32-42. doi: 10.1037/a0022595

Jerjes, W. K., Cleare, A. J., Wessely, S., Wood, P. J., and Taylor, N. F. (2005). Diurnal patterns of salivary cortisol and cortisone output in chronic fatigue syndrome. J. Affect. Disord. 87, 299-304. doi: 10.1016/j.jad.2005.03.013

Jones, D. E., Hollingsworth, K. G., Jakovljevic, D. G., Fattakhova, G., Pairman, J., Blamire, A. M., et al. (2012). Loss of capacity to recover from acidosis on repeat exercise in chronic fatigue syndrome: a case-control study. Eur. J. Clin. Invest. 42, 186-194. doi: 10.1111/j.1365-2362.2011.02567.x

Katch, V. L., Sady, S. S., and Freedson, P. (1982). Biological variability in maximum aerobic power. Med. Sci. Sports Exerc. 14, 21-25. doi: 10.1249/00005768198214010-00004

Katz, B. Z., Stewart, J. M., Shiraishi, Y., Mears, C. J., and Taylor, R. (2011). Autonomic symptoms at baseline and following infectious mononucleosis in a prospective cohort of adolescents. Arch. Pediatr. Adolesc. Med. 165, 765-766. doi: 10.1001/archpediatrics.2011.124

Kaushik, N., Fear, D., Richards, S. C., McDermott, C. R., Nuwaysir, E. F., Kellam, P., et al. (2005). Gene expression in peripheral blood mononuclear cells from patients with chronic fatigue syndrome. J. Clin. Pathol. 58, 826-832. doi: $10.1136 /$ jcp. 2005.025718

Kennedy, G., Khan, F., Hill, A., Underwood, C., and Belch, J. F. (2010). Biochemical and vascular aspects of pediatric chronic fatigue syndrome. Arch. Pediatr. Adolesc. Med. 164, 817-823. doi: 10.1001/archpediatrics.2010.157

Kerr, J. R., Petty, R., Burke, B., Gough, J., Fear, D., Sinclair, L. I., et al. (2008a). Gene expression subtypes in patients with chronic fatigue syndrome/myalgic encephalomyelitis. J. Infect. Dis. 197, 1171-1184. doi: 10.1086/533453

Kerr, J. R., Burke, B., Petty, R., Gough, J., Fear, D., Mattey, D. L., et al. (2008b). Seven genomic subtypes of chronic fatigue syndrome/myalgic encephalomyelitis: a detailed analysis of gene networks and clinical phenotypes. J. Clin. Pathol. 61, 730-739. doi: 10.1136/jcp.2007.053553
Kindlon, T. (2012). Objective compliance and outcome measures should be used in trials of exercise interventions for chronic fatigue syndrome. Eur. J. Clin. Invest. 42, 1360-1361. doi: 10.1111/j.1365-2362.2012.02724.x

Kirschbaum, C., Pirke, K. M., and Hellhammer, D. H. (1993). The 'Trier social stress test' - a tool for investigating psychobiological stress responses in a laboratory setting. Neuropsychobiology 28, 76-81. doi: 10.1159/000119004

Kishi, A., Natelson, B. H., Togo, F., Struzik, Z. R., Rapoport, D. M., and Yamamoto, Y. (2011). Sleep-stage dynamics in patients with chronic fatigue syndrome with or without fibromyalgia. Sleep 34, 1551-1560. doi: 10.5665/sleep.1396

Kishi, A., Struzik, Z. R., Natelson, B. H., Togo, F., and Yamamoto, Y. (2008). Dynamics of sleep stage transitions in healthy humans and patients with chronic fatigue syndrome. Am. J. Physiol. Regul. Integr. Comp. Physiol. 294, R1980-R1987. doi: 10.1152/ajpregu.00925.2007

Klimas, N. G., Salvato, F. R., Morgan, R., and Fletcher, M. A. (1990). Immunologic abnormalities in chronic fatigue syndrome. J. Clin. Microbiol. 28, 1403-1410.

Knoop, H., Bleijenberg, G., Gielissen, M. F., van der Meer, J. W. M., and White, P. D. (2007). Is a full recovery possible after cognitive behavioural therapy for chronic fatigue syndrome? Psychother. Psychosom. 76, 171-176. doi: 10.1159/00009 9844

Komaroff, A. L. (1988). Chronic fatigue syndromes: relationship to chronic viral infections. J. Virol. Methods 21, 3-10. doi: 10.1016/0166-0934(88)90047-X

Komaroff, A. L. (1994). "Clinical presentation and evaluation of fatigue and chronic fatigue syndrome," in Chronic Fatigue Syndrome, ed S. E. Straus (New York; Basel; Hong Kong: Marcel Dekker), 61-84.

Komaroff, A. L., Fagioli, L. R., Doolittle, T. H., Gandek, B., Gleit, M. A., Guerriero, R. T., et al. (1996). Health status in patients with chronic fatigue syndrome and in general population and disease comparison groups. Am. J. Med. 101, 281-290. doi: 10.1016/S0002-9343(96)00174-X

Kovacs, W. J., and Ojeda, S. R. (2011). Textbook of Endocrine Physiology, 6th Edn. Oxford, UK: Oxford University Press.

Lakhan, S. E., and Kirchgessner, A. (2010). Gut inflammation in chronic fatigue syndrome. Nutr. Metab. 7, 79. doi: 10.1186/1743-7075-7-79

LaManca, J. J., Peckerman, A., Walker, J., Kesil, W., Cook, S., Taylor, A., et al. (1999). Cardiovascular response during head-up tilt in chronic fatigue syndrome. Clin Physiol. 19, 111-120. doi: 10.1046/j.1365-2281.1999.00154.x

LaManca, J. J., Sisto, S. A., DeLuca, J., Johnson, S., Lange, G., Pareja, J., et al. (1998). Influence of exhaustive treadmill exercise on cognitive functioning in chronic fatigue syndrome. Am. J. Med. 105, 59S-65S. doi: 10.1016/S00029343(98)00171-5

Lambert, G. P. (2009). Stress-induced gastrointestinal barrier dysfunction and its inflammatory effects. J. Anim. Sci. 87, E101-E108. doi: 10.2527/jas.2008-1339

Lamprecht, M., and Frauwallner, A. (2012). Exercise, intestinal barrier dysfunction and probiotic supplementation. Med. Sport Sci. 59, 47-56. doi: $10.1159 / 000342169$

Lange, G., DeLuca, J., Maldjian, J. A., Lee, H., Tiersky, L. A., and Natelson, B. H. (1999). Brain MRI abnormalities exist in a subset of patients with chronic fatigue syndrome. J. Neurol. Sci. 171, 3-7. doi: 10.1016/S0022-510X(99) 00243-9

Lange, G., Steffener, J., Cook, D. B., Bly, B. M., Christodoulou, C., Liu, W. C., et al. (2005). Objective evidence of cognitive complaints in chronic fatigue syndrome: a BOLD fMRI study of verbal working memory. Neuroimage 26, 513-524. doi: 10.1016/j.neuroimage.2005.02.011

Lawrie, S. M., MacHale, S. M., Cavanagh, J. T., O'Carroll, R. E., and Goodwin, G. M. (2000). The difference in patterns of motor and cognitive function in chronic fatigue syndrome and severe depressive illness. Psychol. Med. 30, 433-442. doi: 10.1017/S0033291799001816

Lerner, A. M., Beqaj, S. H., Fitzgerald, J. T., Gill, K., Gill, C., and Edington, J. (2010). Subset-directed antiviral treatment of 142 herpesvirus patients with chronic fatigue syndrome. Virus Adapt. Treat. 2, 47-57. doi: 10.2147/VAAT.S10695

Leslie, S. B. (1997). Chronic fatigue syndrome: optometric clinical presentation and management. J. Behav. Optom. 8, 155-161.

Lezak, M. D., Howieson, D. B., and Loring, D. W. (2004). Neuropsychological Assessment, 4th Edn. New York, NY: Oxford University Press.

Light, A. R., Bateman, L., Jo, D., Hughen, R. W., Vanhaitsma, T. A., White, A. T., et al. (2012). Gene expression alterations at baseline and following moderate exercise in patients with chronic fatigue syndrome, and fibromyalgia syndrome. J. Intern. Med. 271, 64-81. doi: 10.1111/j.1365-2796.2011.02405.x

Lloyd, A. R., Wakefield, D., and Hickie, I. (1993). Immunity and the pathophysiology of chronic fatigue syndrome. Ciba Found. Symp. 173, 176-187. doi: 10.1002/9780470514382.ch11 
Lo, C. C., Nunes Amaral, L. A., Havlin, S., Ivanov, C., Penzel, T., Peter, J. H., et al. (2002). Dynamics of sleep-wake transitions during sleep. Europhys. Lett. 57, 625-631. doi: 10.1209/epl/i2002-00508-7

Lorusso, L., Mikhaylova, S. V., Capelli, E., Ferrari, D., Ngonga, G. K., and Ricevuti, G. (2009). Immunological aspects of chronic fatigue syndrome. Autoimmun Rev. 8, 287-291. doi: 10.1016/j.autrev.2008.08.003

Lutgendorf, S., Klimas, N. G., Antoni, M., Brickman, A., and Fletcher, M. A. (1995). Relationships of cognitive difficulties to immune measures, depression and illness burden in chronic fatigue syndrome. J. Chronic Fatigue Syndr. 1, 23-41. doi: 10.1300/J092v01n02_03

MacHale, S. M., Cavanagh, J. T., Bennie, J., Carroll, S., Goodwin, G. M., and Lawrie, S. M. (1998). Diurnal variation of adrenocortical activity in chronic fatigue syndrome. Neuropsychobiology 38, 213-217. doi: 10.1159/000026543

Maes, M., Mihaylova, I., Kubera, M., and Bosmans, E. (2007b). Not in the mind but in the cell: increased production of cyclo-oxygenase-2 and inducible NO synthase in chronic fatigue syndrome. Neuro Endocrinol. Lett. 28, 463-469.

Maes, M., Mihaylova, I., and Leunis, J. C. (2007a). Increased serum IgA and IgM against LPS of enterobacteria in chronic fatigue syndrome (CFS): indication for the involvement of gram-negative enterobacteria in the etiology of CFS and for the presence of an increased gut-intestinal permeability. J. Affect. Disord. 99, 237-240. doi: 10.1016/j.jad.2006.08.021

Maes, M., and Twisk, F. N. M. (2010). Chronic fatigue syndrome: Harvey and Wessely's (bio)psychosocial model versus a bio(psychosocial) model based on inflammatory and oxidative and nitrosative stress pathways. BMC Med. 8:35. doi: 10.1186/1741-7015-8-35

Maes, M., Twisk, F. N. M., and Johnson, C. (2012a). Myalgic encephalomyelitis (ME), chronic fatigue syndrome (CFS), and chronic fatigue (CF) are distinguished accurately: results of supervised learning techniques applied on clinical and inflammatory data. Psychiatry Res. 200, 754-760. doi: 10.1016/j.psychres.2012.03.031

Maes, M., Twisk, F. N. M., Kubera, M., and Ringel, K. (2012b). Evidence for inflammation and activation of cell-mediated immunity in myalgic encephalomyelitis/chronic fatigue syndrome (ME/CFS): increased interleukin-1, tumor necrosis factor- $\alpha$, PMN-elastase, lysozyme and neopterin. J. Affect. Disord. 136 933-939. doi: 10.1016/j.jad.2011.09.004

Maes, M., Twisk, F. N. M., Kubera, M., Ringel, K., Leunis, J. C., and Geffard, M (2012c). Increased IgA responses to the LPS of commensal bacteria is associated with inflammation and activation of cell-mediated immunity in chronic fatigue syndrome. J. Affect. Disord. 136, 909-917. doi: 10.1016/j.jad.2011. 09.010

Mathew, S. J., Mao, X., Keegan, K. A., Levine, S. M., Smith, E. L., Heier, L. A., et al. (2009). Ventricular cerebrospinal fluid lactate is increased in chronic fatigue syndrome compared with generalized anxiety disorder: an in vivo $3.0 \mathrm{~T}(1) \mathrm{H}$ MRS imaging study. NMR Biomed. 22, 251-258. doi: 10.1002/nbm.1315

McCully, K. K., and Natelson, B. H. (1999). Impaired oxygen delivery to muscle in chronic fatigue syndrome. Clin. Sci. 97, 603-608. doi: 10.1042/CS199 80372

McHorney, C. A., Ware, J. E. Jr., and Raczek, A. E. (1993). The MOS 36-Item ShortForm Health Survey (SF-36): II. Psychometric and clinical tests of validity in measuring physical and mental health constructs. Med. Care 31, 247-263. doi: 10.1097/00005650-199303000-00006

Meeus, M., Mistiaen, W., Lambrecht, L., and Nijs, J. (2009). Immunological similarities between cancer and chronic fatigue syndrome: the common link to fatigue? Anticancer Res. 29, 4717-4726.

Meeus, M., Nijs, J., Hermans, L., Goubert, D., and Calders, P. (2013). The role of mitochondrial dysfunctions due to oxidative and nitrosative stress in the chronic pain or chronic fatigue syndromes and fibromyalgia patients: peripheral and central mechanisms as therapeutic targets? Expert Opin. Ther. Targets 17, 1081-1089. doi: 10.1517/14728222.2013.818657

Melmed, S., Polonsky, K. S. P., Larsen, R. M. D., and Kronenberg, H. M. (2011). Williams Textbook of Endocrinology, 12th Edn. Philadelphia, PA: Elsevier/Saunders.

Millard, A. L., Valli, P. V., Stussi, G., Mueller, N. J., Yung, G. P., and Seebach, J. D. (2013). Brief exercise increases peripheral blood NK cell counts without immediate functional changes, but impairs their responses to ex vivo stimulation. Front. Immunol. 4:125. doi: 10.3389/fimmu.2013.00125

Miwa, K., and Fujita, M. (2009). Cardiac function fluctuates during exacerbation and remission in young adults with chronic fatigue syndrome and "small heart". J. Cardiol. 54, 29-35. doi: 10.1016/j.jjcc.2009.02.008
Miwa, K., and Fujita, M. (2011). Small heart with low cardiac output for orthostatic intolerance in patients with chronic fatigue syndrome. Clin. Cardiol. 34, 782-786. doi: 10.1002/clc.20962

Mogharnas, M., Gaeini, A. A., Sheikholeslami Vatani, D., and Faraji, H. (2011). Effects of aerobic and anaerobic training on inflammatory markers in rats. Med. Sport 64, 21-30.

Montoya, J. G., Kogelnik, A. M., Bhangoo, M., Lunn, M. R., Flamand, L., Merrihew, L. E., et al. (2013). Randomized clinical trial to evaluate the efficacy and safety of valganciclovir in a subset of patients with chronic fatigue syndrome. J. Med. Virol. 85, 2101-2109. doi: 10.1002/jmv.23713

Myhill, S., Booth, N. E., and McLaren-Howard, J. (2009). Chronic fatigue syndrome and mitochondrial dysfunction. Int. J. Clin. Exp. Med. 2, 1-16.

Nacul, L. C., Lacerda, E. M., Pheby, D., Campion, P., Molokhia, M., Fayyaz, S., et al. (2011). Prevalence of myalgic encephalomyelitis/chronic fatigue syndrome (ME/CFS) in three regions of England: a repeated cross-sectional study in primary care. BMC Med. 9:91. doi: 10.1186/1741-7015-9-91

Natelson, B. H. (2013). Brain dysfunction as one cause of CFS symptoms including difficulty with attention and concentration. Front. Physiol. 4:109. doi: 10.3389/fphys.2013.00109

Natelson, B. H., Weaver, S. A., Tseng, C. L., and Ottenweller, J. E. (2005). Spinal fluid abnormalities in patients with chronic fatigue syndrome. Clin. Diagn. Lab. Immunol. 12, 52-55. doi: 10.1128/CDLI.12.1.52-55.2005

Newton, J. L., Okonkwo, O., Sutcliffe, K., Seth, A., Shin, J., and Jones, D. E. (2007). Symptoms of autonomic dysfunction in chronic fatigue syndrome. QJM 100, 519-526. doi: 10.1093/qjmed/hcm057

Nicolson, G. L., Gan, R., and Haier, J. (2003). Multiple co-infections (Mycoplasma, Chlamydia, human herpes virus-6) in blood of chronic fatigue syndrome patients: association with signs and symptoms. APMIS 111, 557-566. doi: 10.1034/j.1600-0463.2003.1110504.x

Ocon, A. J. (2013). Caught in the thickness of brain fog: exploring the cognitive symptoms of chronic fatigue syndrome. Front. Physiol. 4:63. doi: 10.3389/fphys.2013.00063

Ocon, A. J., Messer, Z., Medow, M., and Stewart, J. (2012). Increasing orthostatic stress impairs neurocognitive functioning in chronic fatigue syndrome with postural tachycardia syndrome. Clin. Sci. 122, 227-238. doi: 10.1042/CS20110241

Papadopoulos, A. S., and Cleare, A. J. (2011). Hypothalamic-pituitary-adrenal axis dysfunction in chronic fatigue syndrome. Nat. Rev. Endocrinol. 8, 22-32. doi: 10.1038/nrendo.2011.153

Parker, A. J., Wessely, S., and Cleare, A. J. (2001). The neuroendocrinology of chronic fatigue syndrome and fibromyalgia. Psychol. Med. 31, 1331-1345. doi: 10.1017/S0033291701004664

Patarca, R., Klimas, N. G., Garcia, M. N., Walters, M. J., Dombroski, D., Pons, H., et al. (1995). Dysregulated expression of soluble immune mediator receptors in a subset of patients with chronic fatigue syndrome: cross-sectional categorization of patients by immune status. J. Chronic Fatigue Syndr. 1, 79-94. doi: 10.1300/J092v01n01_06

Patrick Neary, J., Roberts, A. D., Leavins, N., Harrison, M. F., Croll, J. C., and Sexsmith, J. R. (2008). Prefrontal cortex oxygenation during incremental exercise in chronic fatigue syndrome. Clin. Physiol. Funct. Imaging 28, 364-372. doi: 10.1111/j.1475-097X.2008.00822.x

Paul, L., Wood, L., Behan, W. M., and Maclaren, W. M. (1999). Demonstration of delayed recovery from fatiguing exercise in chronic fatigue syndrome. Eur. J. Neurol. 6, 63-69. doi: 10.1046/j.1468-1331.1999.610063.x

Peckerman, A., LaManca, J. J., Dahl, K. A., Chemitiganti, R., Qureishi, B., and Natelson, B. H. (2003). Abnormal impedance cardiography predicts symptom severity in chronic fatigue syndrome. Am. J. Med. Sci. 326, 55-60. doi: 10.1097/00000441-200308000-00001

Pietrangelo, T., Mancinelli, R., Toniolo, L., Toniolo, L., Vecchiet, J., Fanò, G., et al. (2009). Transcription profile analysis of vastus lateralis muscle from patients with chronic fatigue syndrome. Int. J. Immunopathol. Pharmacol. 22, 795-807.

Porter, N., Lerch, A., Jason, L. A., Sorenson, M., Fletcher, M. A., and Herrington, J. (2010). A comparison of immune functionality in viral versus non-viral CFS subtypes. J. Behav. Neurosci. Res. 8, 1-8.

Puri, B. K., Jakeman, P. M., Agour, M., Gunatilake, K. D., Fernando, K. A. Gurusinghe, A. I., et al. (2012). Regional grey and white matter volumetric changes in myalgic encephalomyelitis (chronic fatigue syndrome): a voxel-based morphometry 3 T MRI study. Br. J. Radiol. 85, e270-e273. doi: $10.1259 /$ bjr/93889091 
Quistorff, B., Secher, N. H., and van Lieshout, J. J. (2008). Lactate fuels the human brain during exercise. FASEB J. 22, 3443-3449. doi: 10.1096/fj.08-106104

Ramsay, A. M. (1988). Myalgic Encephalomyelitis and Postviral Fatigue States: the Saga of Royal Free Disease. London: Gower Medical Publishing.

Ray, C., Jefferies, S., and Weir, W. R. (1997). Coping and other predictors of outcome in chronic fatigue syndrome: a 1-year follow-up. J. Psychosom. Res. 43, 405-415. doi: 10.1016/S0022-3999(97)00111-6

Rechtschaffen, A., and Kales, A. (1968). A Manual of Standardized Terminology, Techniques and Scoring System for Sleep States of Human Subjects. Washington, DC: US Government Printing Office.

Reeves, W. C., Wagner, D., Nisenbaum, R., Jones, J. F., Gurbaxani, B., Solomon, L., et al. (2005). Chronic fatigue syndrome - a clinically empirical approach to its definition and study. BMC Med. 3:19. doi: 10.1186/1741-7015-3-19

Reyes, M., Dobbins, J. G., Nisenbaum, R., Subedar, N., Randall, B., and Reeves, W. C. (1998). Chronic fatigue syndrome progression and self-defined recovery: evidence from the CDC surveillance system. J. Chronic Fatigue Syndr. 5, 17-27. doi: 10.1300/J092v05n01_03

Roelant, C., and de Meirleir, K. (2012). Self-test monitoring of the Th1/Th2 balance in health and disease with special emphasis on chronic fatigue syndrome/myalgic encephalomyelitis. JMLD 3, 1-6. doi: 10.5897/JMLD11.023

Rommelse, N. N., Van der Stigchel, S., and Sergeant, J. A. (2008). A review on eye movement studies in childhood and adolescent psychiatry. Brain Cogn. 68, 391-414. doi: 10.1016/j.bandc.2008.08.025

Rowe, P. C., Bou-Holaigah, I., Kan, J. S., and Calkins, H. (1995). Is neurally mediated hypotension an unrecognised cause of chronic fatigue? Lancet 345 623-624. doi: 10.1016/S0140-6736(95)90525-1

Sakharov, D. A., Maltseva, D. V., Riabenko, E. A., Shkurnikov, M. U., Northoff, H., Tonevitsky, A. G., et al. (2012). Passing the anaerobic threshold is associated with substantial changes in the gene expression profile in white blood cells. Eur. J. Appl. Physiol. 112, 963-972. doi: 10.1007/s00421-011-2048-3

Schutzer, S. E., Angel, T. E., Liu, T., Schepmoes, A. A., Clauss, T. R., Adkins, J. A., et al. (2011). Distinct cerebrospinal fluid proteomes differentiate posttreatment lyme disease from chronic fatigue syndrome. PLoS ONE 6:e17287. doi: 10.1371/journal.pone.0017287

Scott, L. V., Medbak, S., and Dinan, T. G. (1998). The low dose ACTH test in chronic fatigue syndrome and in health. Clin. Endocrinol. (Oxf). 48, 733-737. doi: $10.1046 / j .1365-2265.1998 .00418 . x$

Scott, L. V., Teh, J., Reznek, R., Martin, A., Sohaib, A., and Dinan, T. G. (1999). Small adrenal glands in chronic fatigue syndrome: a preliminary computer tomography study. Psychoneuroendocrinology 24, 759-768. doi: 10.1016/S03064530(99)00028-1

Sharpe, M. C., Archard, L. C., Banatvala, J. E., Borysiewicz, L. K., Clare, A. W., David, A., et al. (1991). Chronic fatigue syndrome: guidelines for research. J. $R$. Soc. Med. 84, 118-121.

Sheedy, J. R., Wettenhall, R. E., Scanlon, D., Gooley, P. R., Lewis, D. P., McGregor, N., et al. (2009). Increased d-lactic acid intestinal bacteria in patients with chronic fatigue syndrome. In Vivo 23, 621-628.

Shungu, D. C., Weiduschat, N., Murrough, J. W., Mao, X., Pillemer, S., Dyke, J. P., et al. (2012). Increased ventricular lactate in chronic fatigue syndrome. III. Relationships to cortical glutathione and clinical symptoms implicate oxidative stress in disorder pathophysiology. NMR Biomed. 25, 1073-1087. doi: $10.1002 / \mathrm{nbm} .2772$

Siegel, S. D., Antoni, M. H., Fletcher, M. A., Maher, K., Segota, M. C., and Klimas, N. (2006). Impaired natural immunity, cognitive dysfunction, and physical symptoms in patients with chronic fatigue syndrome: preliminary evidence for a subgroup. J. Psychosom. Res. 60, 559-566. doi: 10.1016/j.jpsychores.2006.03.001

Siemionow, V., Fang, Y., Calabrese, L., Sahgal, V., and Yue, G. H. (2004). Altered central nervous system signal during motor performance in chronic fatigue syndrome. Clin. Neurophysiol. 115, 2372-2381. doi: 10.1016/j.clinph.2004.05.012

Smylie, A. L., Broderick, G., Fernandes, H., Razdan, S., Barnes, Z., Collado, F., et al. (2013). A comparison of sex-specific immune signatures in Gulf War illness and chronic fatigue syndrome. BMC Immunol. 14:29. doi: 10.1186/1471-2172-14-29

Snell, C. R., Stevens, S. R., Davenport, T. E., and VanNess, J. M. (2013). Discriminative validity of metabolic and workload measurements to identify individuals with chronic fatigue syndrome. Phys. Ther. 93, 1484-1492. doi: $10.2522 / \mathrm{ptj} .20110368$

Stark, T., Walker, B., Phillips, J. K., Fejer, R., and Beck, R. (2011). Hand-held dynamometry correlation with the gold standard isokinetic dynamometry: a systematic review. PM R 3, 472-479. doi: 10.1016/j.pmrj.2010.10.025
Steensberg, A., Toft, A. D., Bruunsgaard, H., Sandmand, M., Halkjaer-Kristensen, J., and Pedersen, B. K. (2001). Strenuous exercise decreases the percentage of type $1 \mathrm{~T}$ cells in the circulation. J. Appl. Physiol. 91, 1708-1712.

Stewart, J. M., Gewitz, M. H., Weldon, A., Arlievsky, N., Li, K., and Munoz, J. (1999). Orthostatic intolerance in adolescent chronic fatigue syndrome. Pediatrics 103, 116-121. doi: 10.1542/peds.103.1.116

Strauss, E., Sherman, E. M. S., and Spreen, O. (2006). A Compendium of Neuropsychological Tests, 3rd Edn. New York: Oxford University Press.

Streeten, D. H. (1987). Orthostatic Disorders of the Circulation: Mechanisms, Manifestations and Treatment. New York, NY: Plenum Medical Book Publishing.

Streeten, D. H., and Anderson, G. H. J. (1998). The role of delayed orthostatic hypotension in the pathogenesis of chronic fatigue. Clin. Auton. Res. 8, 119-124. doi: $10.1007 / \mathrm{BF} 02267822$

Streeten, D. H., and Bell, D. S. (1998). Circulating blood volume in chronic fatigue syndrome. J. Chronic Fatigue Syndr. 4, 3-11. doi: 10.1300/J092v04n01_02

Suárez, A., Guillamo, E., Roig, T., Blázquez, A., Alegre, J., Bermúdez, J., et al. (2010). Nitric oxide metabolite production during exercise in chronic fatigue syndrome: a case-control study. J. Womens. Health (Larchmt). 19, 1073-1077. doi: $10.1089 /$ jwh.2008.1255

Tak, L. M., Cleare, A. J., Ormel, J., Manoharan, A., Kok, I. C., Wessely, S., et al. (2011). Meta-analysis and meta-regression of hypothalamic-pituitary-adrenal axis activity in functional somatic disorders. Biol. Psychol. 87, 183-194. doi: 10.1016/j.biopsycho.2011.02.002

Task Force for the Diagnosis and Management of Syncope, European Society of Cardiology (ESC), European Heart Rhythm Association (EHRA), Heart Failure Association (HFA), and Heart Rhythm Society (HRS). (2009). Guidelines for the diagnosis and management of syncope (version 2009). Eur. Heart J. 30, 2631-2671. doi: 10.1093/eurheartj/ehp298

Thambirajah, A. A., Sleigh, K., Stiver, H. G., and Chow, A. W. (2008). Differential heat shock protein responses to strenuous standardized exercise in chronic fatigue syndrome patients and matched healthy controls. Clin. Invest. Med. 31, E319-E327.

The Medical Staff of The Royal Free Hospital. (1957). An outbreak of encephalomyelitis in the Royal Free Hospital Group, London, in 1955. Br. Med. J. 2, 895-904. doi: 10.1136/bmj.2.5050.895

Thomas, M., and Smith, A. (2009). An investigation into the cognitive deficits associated with chronic fatigue syndrome. Open Neurol. J. 3, 13-23. doi: 10.2174/1874205X00903010013

Tiersky, L. A., Johnson, S. K., Lange, G., Natelson, B. H., and DeLuca, J. (1997). Neuropsychology of chronic fatigue syndrome: a critical review. J. Clin. Exp. Neuropsychol. 19, 560-586. doi: 10.1080/01688639708403744

Tomic, S., Brkic, S., Maric, D., and Mikic, A. N. (2012). Lipid and protein oxidation in female patients with chronic fatigue syndrome. Arch. Med. Sci. 8, 886-891. doi: 10.5114/aoms.2012.31620

Torres-Harding, S., Sorenson, M., Jason, L., Maher, K., Fletcher, M. A., Reynolds, N., et al. (2008). The associations between basal salivary cortisol and illness symptomatology in chronic fatigue syndrome. J. Appl. Biobehav. Res. 13, 157-180. doi: 10.1111/j.1751-9861.2008.00033.x

Twisk, F. N. M., and Arnoldus, R. J. W. (2012). Graded exercise therapy (GET)/cognitive behavioural therapy (CBT) is often counterproductive in myalgic encephalomyelitis (ME) and chronic fatigue syndrome (CFS). Eur. J. Clin. Invest. 42, 1255-1256. doi: 10.1111/j.13652362.2012.02718.x

Twisk, F. N. M., and Arnoldus, R. J. W. (2013). Comment and reply on: ME is a distinct diagnostic entity, not part of a chronic fatigue spectrum. Expert Opin. Med. Diagn. 7, 413-415. doi: 10.1517/17530059.2013.795147

Van der Meer, J. W. M., and Lloyd, A. R. (2012). A controversial consensus - Comment on article by Broderick et al. J. Intern. Med. 271, 29-31. doi: 10.1111/j.1365-2796.2011.02468.x

Van der Ploeg, R. J. O., Fidler, V., and Oosterhuis, H. J. G. H. (1991). Hand-held myometry: reference values. J. Neurol. Neurosurg. Psychiatr. 54, 244-247.

Van der Werf, S. P., de Vree, B., Alberts, M., van der Meer, J. W. M., and Bleijenberg, G. (2002). Netherlands Fatigue Research Group Nijmegen. Natural course and predicting self-reported improvement in patients with chronic fatigue syndrome with a relatively short illness duration. J. Psychosom. Res. 53, 749-753. doi: 10.1016/S0022-3999(02)00324-0

VanNess, J. M., Snell, C. R., Stevens, S. R., Bateman, L., and Keller, B. A. (2006). Using serial cardiopulmonary exercise tests to support a diagnosis of chronic fatigue syndrome. Med. Sci. Sports Exerc. 38, S85. doi: 10.1249/00005768200605001-00386 
VanNess, J. M., Snell, C. R., Stevens, S. R., and Stiles, T. L. (2007). Metabolic and neurocognitive responses to an exercise challenge in chronic fatigue syndrome (CFS). Med. Sci. Sports Exerc. 39, S445. doi: 10.1249/01.mss.0000274760.28522.df

Vedelago, L. J. (1997). Visual dysfunction in chronic fatigue syndrome: behavioural optometric assessment and management. J. Behav. Optom. 8, 149-154.

Vercoulen, J. H. M. M., Swanink, C. M. A., Fennis, J. F. M., Galama, J. M. D., van der Meer, J. W. M., and Bleijenberg, G. (1994). Dimensional assessment of chronic fatigue syndrome. J. Psychosom. Res. 38, 383-392. doi: 10.1016/00223999(94)90099-X

Vermeulen, R. C., and Vermeulen van Eck, I. W. (2014). Decreased oxygen extraction during cardiopulmonary exercise test in patients with chronic fatigue syndrome. J. Transl. Med. 12, 20. doi: 10.1186/1479-5876-12-20

Vermeulen, R. C. W., Kurk, R. M., Visser, F. C., Sluiter, W., and Scholte, H. R. (2010). Patients with chronic fatigue syndrome performed worse than controls in a controlled repeated exercise study despite a normal oxidative phosphorylation capacity. J. Transl. Med. 8, 93. doi: 10.1186/1479-5876-8-93

Wang, C. Y., Olson, S. L., and Protas, E. J. (2002). Test-retest strength reliability: hand-held dynamometry in community-dwelling elderly fallers. Arch. Phys. Med. Rehabil. 83, 811-815. doi: 10.1053/apmr.2002.32743

Ware, J. E. Jr., Sherbourne, C. D. (1992). The MOS 36-item short-form health survey (SF-36). I. Conceptual framework and item selection. Med. Care 30, 473-483. doi: 10.1097/00005650-199206000-00002

Watson, W. S., McCreath, G. T., Chaudhuri, A., and Behan, P. O. (1997). Possible cell membrane transport defect in chronic fatigue syndrome? J. Chronic Fatigue Syndr. 3, 1-13. doi: 10.1300/J092v03n03_01

Watt, T., Oberfoell, S., Balise, R., Lunn, M. R., Kar, A. K., Merrihew, L., et al. (2012). Response to valganciclovir in chronic fatigue syndrome patients with human herpesvirus 6 and Epstein-Barr virus IgG antibody titers. J. Med. Virol. 84, 1967-1974. doi: 10.1002/jmv.23411

Wechsler, D. (1981). Wechsler Adult Intelligence Scale-revised. San Antonio, TX: The Psychological Corporation.

Weinstein, A. A., Drinkard, B. M., Diao, G., Furst, G., Dale, J. K., Straus, S. E., et al. (2009). Exploratory analysis of the relationships between aerobic capacity and self-reported fatigue in patients with rheumatoid arthritis, polymyositis, and chronic fatigue syndrome. PM R 1, 620-628. doi: 10.1016/j.pmrj.2009.04.007

Whistler, T., Jones, J. F., Unger, E. R., and Vernon, S. D. (2005). Exercise responsive genes measured in peripheral blood of women with chronic fatigue syndrome and matched control subjects. BMC Physiol. 5:5. doi: 10.1186/1472-6793-5-5

Whistler, T., Unger, E. R., Nisenbaum, R., and Vernon, S. D. (2003). Integration of gene expression, clinical, and epidemiologic data to characterize chronic fatigue syndrome. J. Transl. Med. 1, 10. doi: 10.1186/1479-5876-1-10

White, A. T., Light, A. R., Hughen, R. W., Bateman, L., Martins, T. B., Hill, H. R., et al. (2010). Severity of symptom flare after moderate exercise is linked to cytokine activity in chronic fatigue syndrome. Psychophysiology 47, 615-624. doi: 10.1111/j.1469-8986.2010.00978.x

White, A. T., Light, A. R., Hughen, R. W., Vanhaitsma, T. A., and Light, K. C. (2012). Differences in metabolite-detecting, adrenergic, and immune gene expression after moderate exercise in patients with chronic fatigue syndrome, patients with multiple sclerosis, and healthy controls. Psychosom. Med. 74, 46-54. doi: 10.1097/PSY.0b013e31824152ed

White, P. D., Goldsmith, K. A., Johnson, A. L., Potts, L., Walwyn, R., DeCesare, J. C., et al. (2011). Comparison of adaptive pacing therapy, cognitive behaviour therapy, graded exercise therapy, and specialist medical care for chronic fatigue syndrome (PACE): a randomised trial. Lancet 377, 823-836. doi: 10.1016/S01406736(11)60096-2

WHO. (1967). International Classification of Diseases. Eighth Revision I (code 323), Geneva, IL: World Health Organization.

WHO. (1992). International Classification of Diseases. Tenth Revision (code G93.3), Geneva, IL: World Health Organization.

Wilson, A., Hickie, I., Hadzi-Pavlovic, D., Wakefield, D., Parker, G., Straus, S. E., et al. (2001). What is chronic fatigue syndrome? Heterogeneity within an international multicentre study. Aust. N.Z. J. Psychiatry 35, 520-527. doi: 10.1046/j.1440-1614.2001.00888.x

Wyller, V. B., Due, R., Saul, J. P., Amlie, J. P., and Thaulow, E. (2007). Usefulness of an abnormal cardiovascular response during low-grade head-up tilt-test for discriminating adolescents with chronic fatigue from healthy controls. Am. J. Cardiol. 99, 997-1001. doi: 10.1016/j.amjcard.2006.10.067

Yoshiuchi, K., Farkas, J., and Natelson, B. H. (2006). Patients with chronic fatigue syndrome have reduced absolute cortical blood flow. Clin. Physiol. Funct. Imaging 26, 83-86. doi: 10.1111/j.1475-097X.2006.00649.x

Zhang, C., Baumer, A., Mackay, I. R., Linnane, A. W., and Nagley, P. (1995). Unusual pattern of mitochondrial DNA deletions in skeletal muscle of an adult human with chronic fatigue syndrome. Hum. Mol. Genet. 4, 751-754. doi: $10.1093 / \mathrm{hmg} / 4.4 .751$

Zhang, L., Gough, J., Christmas, D., Mattey, D. L., Richards, S. C., Main, J., et al. (2010). Microbial infections in eight genomic subtypes of chronic fatigue syndrome/myalgic encephalomyelitis. J. Clin. Pathol. 63, 156-164. doi: 10.1136/jcp.2009.072561

Conflict of Interest Statement: The author declares that the research was conducted in the absence of any commercial or financial relationships that could be construed as a potential conflict of interest.

Received: 06 February 2014; accepted: 04 March 2014; published online: 27 March 2014.

Citation: Twisk FNM (2014) The status of and future research into Myalgic Encephalomyelitis and Chronic Fatigue Syndrome: the need of accurate diagnosis, objective assessment, and acknowledging biological and clinical subgroups. Front. Physiol. 5:109. doi: 10.3389/fphys.2014.00109

This article was submitted to Exercise Physiology, a section of the journal Frontiers in Physiology.

Copyright (C) 2014 Twisk. This is an open-access article distributed under the terms of the Creative Commons Attribution License (CC BY). The use, distribution or reproduction in other forums is permitted, provided the original author(s) or licensor are credited and that the original publication in this journal is cited, in accordance with accepted academic practice. No use, distribution or reproduction is permitted which does not comply with these terms. 